\title{
ON THE APPEARANCE AND SIGNIFICANCE OF FUNGI AND BACTERIA ANTIBIOTICALLY AFFECTING THE FUNGUS SCLEROTINIA TRIFOLIORUM ERIKSS.
}

\author{
Onni Pohjakallio and Arvi Salonen. \\ Institute of Plant Pathology, University of Helsinki.
}

Received 10. 4. 1950.

\section{Introduction}

Attempts to grow Sclerotinia trifoliorum ERIKss. on frozen clover have often proved a failure (1). However frozen clover in itself is an excellent medium for S. trifoliorum, but it will often be coated with different antibiotic bacteria (2). In autumn 1948, at the Experimental Farm of Helsinki University, Viiks Manor, a Pseudomonas species was isolated from a frozen clover leaf, which even at a low temperature had an antibiotic effect, and which thus hindered the spread of the mycelium of S. trifoliorum to the frozen leaves of the clover (2). In order to obtain further information on the appearance of antibiotic bacteria and other antibiotic microbes on clover at Viiks Manor, some investigations were made in the following autumn (1949) to throw light on this question. In these investigations attention was directed to damage caused by S. trifoliorum to red clover (Trifolium pratense L.), to the freezing of red clover leaves by autumn frosts, and to the appearance of antibiotic bacteria and fungi on frozen leaves of red clover.

The freezing of red clover leaves by autumn frosts.

The minimum temperature in the night between 6 th and 7 th October was about $-10^{\circ} \mathrm{C}$ near the surface of the ground. The following day the temperature rose above the freezing-point, and there were many withered leaves of clover to be seen. A great part of the withered leaves died and became brown. After this there were many frosty nights resulting in still more frozen leaves. On December 4 th, when the last observation was made, the outermost leaves of the clover rosettes were frozen and brown-coloured throughout. 


\section{The appearance of antibiotic bacteria and fungi.}

On November 13 th (temperature $+3,5^{\circ} \mathrm{C}$ ) and 18 th (temperature $+2{ }^{\circ} \mathrm{C}$ ) samples of fungi and bacteria appearing on red clover leaves were taken at Viiks. Manor from ten plots, the greatest distance between them being about 2 kilometres. The samples were transferred with a sterile platinum wire to sterile nutrient agar streak cultures, and at random without observing whether any bacterium or fungus flora could be seen on the clover leaf. On November 13 th 100 samples were transferred to Henneberg-agar (cf. 2) and on November 18th, 100 samples to clover extract agar. Bacteria and fungi grown on the nutrient media were further inoculated to clover extract agar in Petri dishes. To investigate the antibiotic effect of these, S. trifoliorum was inoculated into the same Petri dishes, too.

In three of the tubes no growth appeared, but in the other 197 tubes there developed different bacteria and fungi, often many species in the same tube. When some mould fungus species rapidly covered the surface of the medium, it was only possible to note down exactly the most rapidly growing of the bacterial colonies and fungus species, which therefore were the easiest to obtain. The investigation of the antibiotic effect was extended, however, also to some of those fungal and bacterial species, of which it was impossible to discover in how many tubes they had been caught.

Both on the Henneberg-agar medium and on the clover extract agar medium, one Penicillium sp. predominated (cf. table), which had no antibiotic effect on S. trifoliorum. Also one bacterium species, which was easy to recognize from its. red-coloured colonies, had no antibiotic effect. It appeared in several samples on Henneberg-agar, but not at all in samples on clover extract. In general, it seemed that the antibiotic fungi and bacteria were not as able to hold their own against the other microflora on Henneberg-agar medium as they were on clover extract agar medium, on which they more easily secured the substrata and for this reason they were easier to isolate. Earlier (2.), we have established too that the antibiotic effect of a Pseudomonas species on S. trifoliorum and on different mould fungi appeared very clearly on clover extract medium, but did not appear at all on Henne-

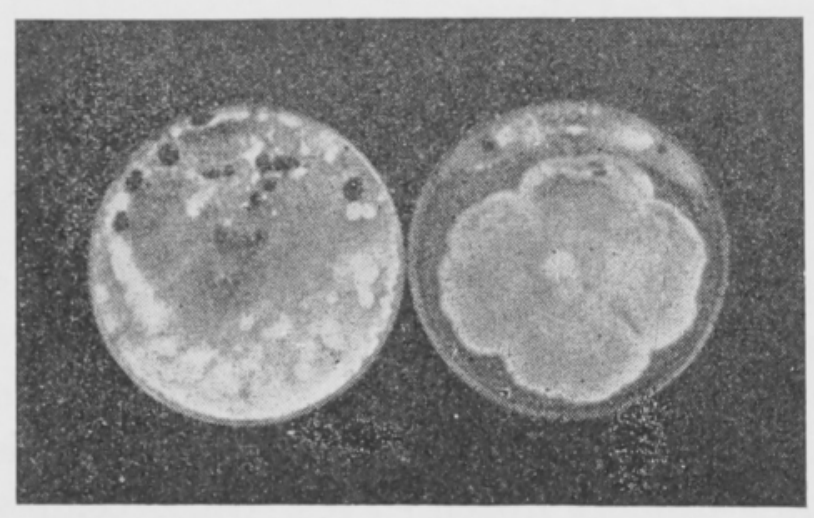

Figure 1. S. trifolior $u m$ alone and together with a Penicillium sp. (table: $A 6$ and $B$ 3) affecting it antibiotically.

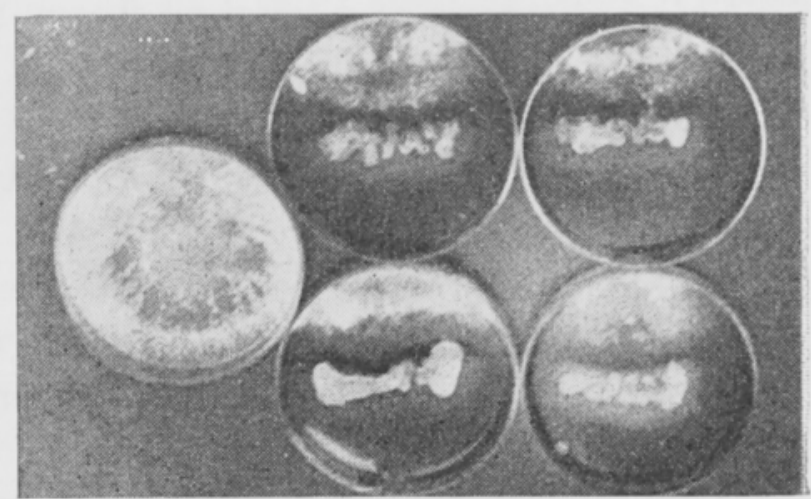

Figure 2. S. trifolior $u m$ alone and together with a bacterium (table: B4) affecting it antibiotically. 
Fungi and bacteria taken from frozen clover leaves and their antibiotic effect on S. trifolior u m.

\begin{tabular}{|c|c|c|c|c|c|}
\hline \multicolumn{2}{|l|}{$\begin{array}{l}\text { Appearance of fungi and bacteria on } \\
\text { original samples }\end{array}$} & \multicolumn{4}{|c|}{$\begin{array}{l}\text { Analysis of the antibiotic } \\
\text { effect (No. of samples) }\end{array}$} \\
\hline \multirow[t]{2}{*}{ Fungi and bacteria } & \multirow{2}{*}{$\begin{array}{c}\text { No. of } \\
\text { samples }\end{array}$} & \multirow{2}{*}{$\begin{array}{l}\text { Samples } \\
\text { investigated }\end{array}$} & \multicolumn{3}{|c|}{ Antibiotic effect } \\
\hline & & & Lacking & Weak & Stror \\
\hline A. Henneberg-Agar Medium & & & & & \\
\hline 1. No growth $\ldots \ldots \ldots \ldots \ldots \ldots \ldots$ & 2 & - & - & - & - \\
\hline 2. S. trifoliorum $\quad \ldots \ldots \ldots \ldots \ldots \ldots$ & 1 & - & - & - & - \\
\hline 3. Penicillium sp............... & 92 & 5 & 5 & 0 & 0 \\
\hline 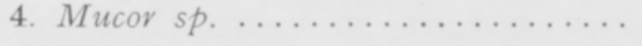 & 5 & 1 & 1 & 0 & 0 \\
\hline 5. Fusarium sp. $\quad \ldots \ldots \ldots \ldots \ldots \ldots$ & $?$ & 1 & 1 & 0 & 0 \\
\hline 6. Different fungus species $\ldots \ldots \ldots \ldots$ & ? & 4 & 2 & 1 & 1 \\
\hline 7. Red bacterial colonies .......... & 54 & 14 & 14 & 0 & 0 \\
\hline $\begin{array}{l}\text { 8. Pale bacterial colonies } \ldots \ldots \ldots \ldots \\
\text { B. Clover Extract Agar Medium }\end{array}$ & ? & 6 & 0 & 2 & 4 \\
\hline 1. No growth $\ldots \ldots \ldots \ldots \ldots \ldots \ldots$ & 1 & 一 & - & - & - \\
\hline 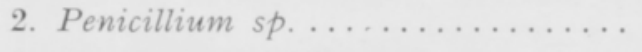 & 99 & 1 & 1 & 0 & 0 \\
\hline 3. Another Penicillium sp. ......... & ? & 1 & 0 & 0 & 1 \\
\hline 4. Greyish-yellow bact. colon. . .... & 43 & 8 & 0 & 0 & 8 \\
\hline 5. Yellow bact. colonies $\ldots \ldots \ldots \ldots$ & 6 & 6 & 0 & 4 & 2 \\
\hline
\end{tabular}

berg-agar medium. However it was possible to isolate also from Henneberg agar medium some bacteria which, when inoculated into clover extract agar, had an antibiotic effect (table: A 8). One Penicillium sp. too (table: A 6 and B 3), which on the artificial substratum formed reproductive organs very slowly, was antibiotically effective against S. trifoliorum. It stopped the growth of the mycelium of S. trifoliorum already at a distance of $2-3$ centimetres from the bacterial colonies and finally the fungus grew, although with difficulty, beyond the mycelium of S. trifoliorum (figure 1).

In many samples, on clover extract agar, there was obtained a red bacterium species forming greyish-yellow colonies (table: B 4). This bacterium had a very strong antibiotic effect on S. trifoliorum (table: B 4 and figure 2). It stopped the spread of the mycelium of S.trifoliorum on the surface of the agar, and in some cultures at $5^{\circ}-10^{\circ} \mathrm{C}$, the edge of the mycelium rose from the substratum to the cover of the Petri dish and grew there above the bacterial colonies; in figure 2 there is to be seen a thin mycelial fringe rising from the substratum.

In this investigation it has been established that at least three fungus species and a few bacterium species with an antibiotic effect on S. trifoliorum had been obtained in the samples from the frozen leaves. They had besides been found in so many samples that they were to be regarded as very common in the fields of Viiks Manor. And as they were taken from frozen clover leaves and were antibiotically effective on S. trifoliorum on clover extract substratum, it is probable that in nature they hinder $S$. trifoliorum from growing on the dead leaves of clover. 


\section{The appearance of clover rot in meadows of Viiks Manor in autumn 1949.}

In the meadows of Viiks Manor in autumn 1949 the clover rot appeared to be quite widespread at least from the beginning of October, when proper observations were started. It was found, however, generally only in small patches $1-2 \mathrm{sq}$.dcm. in extent. During the autumn, incidence of clover rot increased a little, but the dimensions of the patches attacked remained throughout small, though, temperature conditions in late autumn were favourable for the spread of clover rot. Thus the damage by clover rot before winter (latest observation 4th Dec.) was of no practical importance. From the foregoing account, it seems that the outermost leaves of the clover rosettes, which were frozen throughout on account of night frosts, were covered with antibiotic bacteria and fungi which prevented the spread of the mycelium of S. trifoliorum from one clover plant to another.

\section{Sum mary.}

At the Experimental Farm of Helsinki University, Viiks Manor, there were isolated from frozen clover leaves bacteria and fungi, which grew even at low temperatures and had an antibiotic effect on the clover rot fungus (Sclerotinia trifoliorum ERIKSS.)

The antibiotic fungi and bacteria proved to be so common that they obviously restricted the growth of the clover rot fungus on the frozen leaves of clover.

When on account of night frosts the outermost leaves of the clover rosette were killed throughout, they formed, in consequence of the fungi and bacteria, antibiotic zones that limited the spread of the clover rot fungus.

It was probably in the main for this reason that the clover rot, even though it was common in autumn 1949, appeared almost entirely only as $1-3 \mathrm{sq}$.dcm. patches, and thus its damage during the autumn had no practical importance.

\section{LITERATURE.}

(1) Pohjakallio Onni 1947. Om orsakerna till resistens mot Sclerotinia trifolionum. Beretning om Nordiske Jordbrugsforskeres forening syvende Kongres. Oslo, p. 598-605.

(2) - - Salonen Arvi and Laakkonen Eini 1949. Investigations into the Bacteria Antibiotically Affecting the Fungus Sclerotinia trifoliorum Erikss. Physiologia Plantarum, 2, p. $312-322$. 
SEL OS T US.

\section{APILAMÄTÄSIENEEN (SCLEROTINIA TRIFOLIORUM ERIKSS.) ANTIBIOOTTISESTI VAIKUTTAVIEN SIENIEN JA BAKTEERIEN ESIINTYMISESTÄ SEKÄ MERKITYKSESTÄ.}

Onni Pohjakallio ja Arvi Salonen.

Helsingin Yliopiston kasvipatologinen laitos, Helsinki.

Syksyllä 1949 esiintyi Helsingin yliopiston opetus- ja koetilan, Viikin Kartanon, niitto- ja laidun: nurmilta, paleltuneilta apilan lehdiltä otetuissa näytteissä bakteereita ja sieniä, jotka kasvoivat alhaisessakin lämpötilassa ja joilla oli antibioottinen vaikutus apilamädän aiheuttajaan (Sclerotinia trifoliorum ERIKSS.). Nämä antibioottiset bakteerit ja sienet osoittautuivat niin yleisiksi, että ne ilmeisesti estivät apilamädän aiheuttajan kasvamisen apilan paleltuneille lehdille. Kun yöpakkasten vaikutuksesta apilan lehtiruusukkeen uloimmat lehdet jokseenkin kauttaaltaan kuolivat, muodostui niistä antibioottisten bakteerien ja sienien välityksellä vyöhykkeitä, jotka rajoittivat apilamädän leviämistä. Tämä oli todennäköisesti tärkeänä syynä siihen, että ápilamätä, joskin se syksyllä 1949 oli yleinen, ilmeni lähes kauttaaltaan vain $1-3 \mathrm{dm}^{2}$ :n laajuisena esiintyminä, joten sen tuho syksyn kuluessa jäi jokseenkin merkityksettömäksi. 